\title{
Islamic Banking in the Global Financial System: Current Situation and Global Environment
}

\author{
Vladimir Novikov \\ Department of State and Municipal Administration \\ Kuban State Technological University \\ Krasnodar, Russia \\ E-mail: vs.novikov@mail.ru
}

Elena Yarushkina

Director of the Institute of Economics, Management and

Social Communications

Academy of Marketing and Social Information

Technologies - IMSIT (Krasnodar)

Krasnodar, Russia

E-mail: lenayr@yandex.ru

\author{
Elena Britikova \\ Department of Management \\ Kuban State Agrarian University \\ Krasnodar, Russia \\ E-mail: britikova-2011@mail.ru \\ Lydia Kovalenko \\ Department of Management \\ Kuban State Agrarian University \\ Krasnodar, Russia \\ E-mail: kovalenko0801@yandex.ru
}

\begin{abstract}
It happens with ever-increasing frequency that the modern world financial system, based on the theories and practices by Western economists, malfunctions and results in global crises. In this regard, the USA and European economists themselves doubt this system's universality and applicability to all the countries of the world. Until recently, the Islamic economic theory excited nothing more than just academic interest among a limited circle of scientists in the Western world. Nevertheless, under the conditions of today, the Islamic economic model, its structure and mechanisms is a topical subject, as the rise in the gross national product and economic upturn are now observable only in the PRC and Islamic countries. The world economic system has entered and is going through a new stage of development, where the consequences in the globalizing world economy are hard to predict. The system is characterized with growing instability, as it is mostly dependent upon one country - the USA. In the modern economic space, the Islamic economy in general and its banking system in particular are becoming more relevant, as the developed financial situation makes more and more economists and politicians concerned about finding new principles and tools. In some Western countries, such as the United States and the United Kingdom, Islamic banks have become remarkably widespread.
\end{abstract}

Keywords-Islamic banks; banking products; Islamic banks assets; the global financial market; banking

\section{INTRODUCTION}

Islamic banks, the main characteristic feature of which is not charging interest on bank operations, have become an important part of the financial systems of Arab oil-exporting countries. Having certain influence on the way the regional financial systems function, they still play a secondary role, when it comes to the world's banking practice. It can be well explained by several reasons.
First, Islamic banks are a new phenomenon in the economic life of the modern world. It being rather specific, the world banking community cannot but feel alert and adopt a "wait-and-see" approach.

Second, Islamic banks have to compete with traditional commercial banks, which maintain their strong presence in the financial structure of the Arab countries and have established connections with banks around the world.

Third, Islamic banks are now in the institution-building stage of organizational development, and are deciding on the tactics and strategies for adapting to the world's banking community. Therefore, the formation of the organizational and technical basis for Islamic banking has not been completed yet. The whole system appears to be mobile, partly unbalanced, with the opportunities and potential of its interaction with traditional banking structures not being fully exploited.

Fourth, the Islamic banking ideology and the methodology for the functioning of institutions have not yet been well-established. They are still gaining experience with the financial environment.

The Islamic banking market still represents the regional market, which possesses a number of specific features that not only allow scientists to call it an "alternative model" of banking business, but also characterize it as more crisisresistant. According to a conducted study, "in 2017, the total assets of Islamic banks would increase by 13.1 billion dollars" [1].

Special attention should be paid to mutual integration processes: "on the one hand, we observe the adaptation of European banking products to Islamic law, while on the other hand - the introduction of the Islamic principles of 
banking business: sharing risks and establishing partnership with the client" [2]. Some Islamic banking products formed within the integration of the mechanisms and principles of European and Islamic banking are presented in "Table I".

TABLE I. MAIN ISLAMIC BANK SERVICES COMMONLY USED WORLDWIDE [3]

\begin{tabular}{|l|l|}
\hline \multicolumn{1}{|c|}{$\begin{array}{c}\text { Banking } \\
\text { product }\end{array}$} & \multicolumn{1}{|c|}{ Banking product characteristics } \\
\hline Mudarabah & $\begin{array}{l}\text { Trust financing. A bank may act as a manager } \\
\text { (when working with depositor" funds), and } \\
\text { then as a client (when financing a project). }\end{array}$ \\
\hline Musharakah & $\begin{array}{l}\text { Joint project or transaction implementation by } \\
\text { a bank and an entrepreneur. }\end{array}$ \\
\hline Murabaha & $\begin{array}{l}\text { Financing an operation (usually trade } \\
\text { operation) under the principle of "cost plus } \\
\text { profit", mainly on an instalment plan }\end{array}$ \\
\hline Ijara & Leasing operation \\
\hline
\end{tabular}

Multinational companies that extended their influence worldwide through developing an international lending system had a significant role in cultivating international relations and transforming Islamic banking.

\section{METHODS}

The object of the current study is the Islamic bank as an institution of modern international relations. The research is focused on the major directions and trends in the relationship between international corporations and Islamic banks.

The main methods applied to the research include the following: logical, comparative, historical, systemic, functional, analysis and synthesis methods.

The methodology for the present research includes the fundamental principles of providing banking products, the main approaches to banking system construction, the economic theories of market regulation, the concepts of the banking products market influence on the economic processes and the research by Russian scientists on the specifics of the banking market. The study is based on the concepts and ideas of the classical political economy about the mechanisms of market economy, its regulatory functions and principles and on the nature of capital, etc.

\section{RESULTS}

The Islamic financial industry accounts for less than one percent of global financial assets and is characterized with more than $20 \%$ annual growth, since 2002-2012. The increasing demand, in both Islamic financial enterprise and retail markets, is one of the factors stimulating sector growth. Banks represent the core segment of this sector and a small but growing segment of the global banking industry.

A dramatic increase in the growth of Islamic banking in late 20th - early 21 st century encouraged large traditional banks to pay assiduous attention to providing alternative products by means of establishing the so-called "Islamic windows". Emerging and operating in the common financial environment, Islamic banks are confronted with the problem of sustaining competitiveness in the market.

What is more, these banks have to observe Sharia. As researchers say, Islamic finance is currently working in 105 countries, most of which have already adapted the legislation aimed at providing a regulatory framework for the industry (and 18 more are considering its introduction). In the Islamic world itself, these financial institutions are becoming major economic actors.

Throughout the history of Islamic finance, this system has proved efficient and economically viable under capitalism. The total assets of Islamic banks in the world account for more than 1.46 trillion dollars. In early 2013, the annual increment of growth amounted to more than $18 \%$. In spite of the fact that in comparison with traditional banking, the share of the alternative sector currently looks modest, the leading banking corporations, realizing the enormous potential in this area, are already getting into this market.

In this regard, the key role of the Islamic Development Bank (IsDB) in sector development is worth mentioning. It implies creating supporting and regulatory institutions, such as the Accounting and Auditing Organization for Islamic Financial Institutions (AAOIFI), Islamic International Rating Agency (IIRA), the Islamic Financial Services Board (IFSB), the International Islamic Financial Market (IIFM), Liquidity Management Centre (LMC) and The Council of Islamic Banks and Financial Institutions (CIBAFI) [10].

Islamic banking has some notable features, which distinguish it from traditional banking. This fact is confirmed by foreign researchers (see "Table II").

TABLE II. MAJOR DIFFERENCES BETWEEN ISLAMIC BANKS AND TRADITIONAL BANKS [5]

\begin{tabular}{|l|l|l|}
\hline \multicolumn{1}{|c|}{ Characteristics } & \multicolumn{1}{|c|}{ Islamic bank } \\
\hline Guaranteed payments on demand deposits & Yes & Yes \\
\hline Guaranteed payments on investment deposits & No & Yes \\
\hline Interest rate on deposits & Not defined, not guaranteed for investment deposits & Defined and guaranteed \\
\hline $\begin{array}{l}\text { The mechanism to determine the interest rate on } \\
\text { deposits }\end{array}$ & It is determined by bank profits, investment returns & Does not depend on bank profits \\
\hline Depositors' participation in profit and loss of the bank & Yes & Practically none \\
\hline Using Islamic banking products & Yes & $\begin{array}{l}\text { In case of depositors' participation in profits and losses } \\
\text { of an Islamic bank, it mostly does not have the right to } \\
\text { discriminate against customers on the ground of their } \\
\text { collateral }\end{array}$ \\
\hline $\begin{array}{l}\text { The bank's right to decide on disbursement of loalways } \\
\text { depending on the collateral }\end{array}$ & Yes, alwank \\
\hline
\end{tabular}


Islamic banking is focused on generating income not through investment activities (musharaka), but through sales profits (murabaha). This shift from financing through equity financial instruments and profit and loss sharing arrangements to debt financing, leads to underestimating the benefits of other methods of Islamic financing, thus threatening financial stability and sustainable development.

This situation may well be explained by lower risk levels associated with noninvestment instruments. The diagram in "Fig. 1" clearly demonstrates, that the greater part, over $75 \%$, of Islamic banks financing worldwide is in the form of murabaha, the second position is leasing (Ijara) - about $11 \%$. The shares of contracts based on profit distribution (musharakah and mudarabah), constitute about $4 \%$ and $1 \%$, respectively.

The number of Qard-al-Hasan agreements accounts for only $1 \%$. In general, Islamic banking products with profit distribution account for less than $8 \%$ of the total Islamic finance around the world [5].

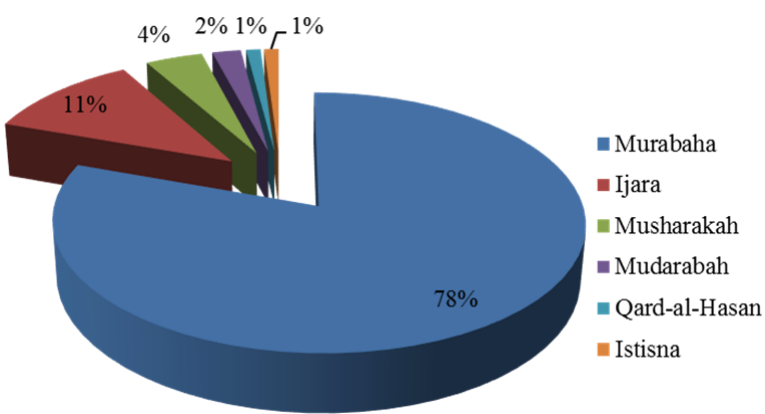

Fig. 1. Islamic banking financial instruments (the share in total funding, \%) [5].

Further analysis of the financial component of the assets demonstrates that despite a wide range of Islamic instruments, murabaha is the most widely applied type of financing. In some countries, its share accounts for about $90 \%$, in others - not less than $50 \%$. The average share of murabaha in total funding within the region constitutes $75 \%$. Leasing ranks second in Bahrain, Jordan, Kuwait, Lebanon and Qatar. Notably, mudarabah financing, which is quite rare in other countries, comes second in Saudi Arabia.

A quantitative data on Islamic financial organizations is presented by the example of some countries where Islamic banking is the main financial instruments (see "Table III"). deposits for short-term unrestricted deposits, demand of funds attracted by banks in 2008, demand deposits constituted 32\%; mudarabah investment accounts - 48.2\%; mudarabah savings accounts $-6.2 \%$.

It is important that Islamic banking institutions are considered Islamic not by the geography of their capital, but primarily by their principles of operational and investment activities. As it was stated earlier in the article, Islamic banks carry out financial transactions in strict compliance with the principles of Sharia.

Therefore, the system of Islamic banks is definitely specific, with banks themselves being separate parts in the structure of international banking. To a greater extent, 
TABLE III. ISLAMIC FINANCIAL INSTITUTIONS: QUANTITATIVE INFORMATION [1]

\begin{tabular}{|l|l|l|l|l|l|l|l|}
\hline & $\begin{array}{c}\text { Islamic } \\
\text { banks }\end{array}$ & $\begin{array}{c}\text { Financial and } \\
\text { investment } \\
\text { companies }\end{array}$ & $\begin{array}{c}\text { Islamic } \\
\text { banking } \\
\text { windows }\end{array}$ & $\begin{array}{c}\text { Takaful } \\
\text { companies }\end{array}$ & $\begin{array}{c}\text { Islamic } \\
\text { insurance } \\
\text { windows }\end{array}$ & Quantity & Share \\
\hline Bahrain & 27 & 5 & 10 & 10 & 0 & 52 & $21 \%$ \\
\hline Saudi Arabia & 6 & 21 & 8 & 28 & 2 & 65 & $26 \%$ \\
\hline Kuwait & 5 & 54 & 2 & 12 & 1 & 74 & $30 \%$ \\
\hline Qatar & 6 & 5 & 5 & 4 & 2 & 2 & $9 \%$ \\
\hline $\begin{array}{l}\text { United Arab } \\
\text { Emirates }\end{array}$ & 8 & 10 & 7 & 10 & 0 & 0 & $14 \%$ \\
\hline Quantity & 52 & 95 & 32 & 64 & 5 & 5 & \\
\hline Share & $21 \%$ & $38 \%$ & $13 \%$ & $26 \%$ & $2 \%$ & $2 \%$ & $100 \%$ \\
\hline
\end{tabular}

The predominant group of Islamic financial organizations is financial and investment companies, $38 \%$ of the total number. Takaful companies account for almost a third, and Islamic banks for $21 \%$ of the total number of Islamic financial organizations. Geographically, most companies $(30 \%)$ are registered in Kuwait, $73 \%$ of which being financial and investment companies. Saudi Arabia has the second highest rate of Islamic financial organizations (approximately 26\%), then comes Bahrain, where Islamic banks are most concentrated (about $50 \%$ of the total number of Islamic banks). The Islamic financial organizations of the United Arab Emirates and Qatar, in their turn, account for a quarter of the total number.

Islamic financial institutions provide alternative opportunities for national enterprises and banks to receive borrowed resources. The pioneering country to implement the Islamic banking system in Europe was Germany, where in 2015, the first Islamic bank was established. It was the KT Bank AG bank, owned by the Kuwait-Turkish financial institution Kuveyt Türk Bank, and was aimed at providing financial services to the German Muslim audience of 4-5 million people. Besides, the bank is intent upon attracting investments from small and medium-sized enterprises, real estate agents, as well as investors from Kuwait. The bank will not finance trade in arms, alcohol and tobacco, and, in line with Islamic principles, it is not allowed to charge interest.

Such ethical financial institutions are not so numerous in the world, including the Arab world. In Turkey, for example, they constitute from 5 to $7 \%$ of banks in total. In future, Islamic financial institutions are expected to excite even more interest, and continue to attract clients, including nonMuslims.

\section{DISCUSSION}

The countries of the Middle East and Asia, including the key members of Muslim countries, are becoming increasingly significant. The G20 Summit, playing a major role in the international economic policy, now includes three members of the Islamic Development Bank and the Organization of Islamic Cooperation - Indonesia, Turkey, and Saudi Arabia. These changes provide ample opportunities for the Islamic financial industry, among them are the following:

- managing savings and the generated capital;
- maintaining sustainable economic growth through financing;

- exercising increased influence in global forums and decision-making organizations

Global forums and decision-making organizations include the G20, the International Monetary Fund and the World Bank Forum, as well as new forums on emerging economies in Asia, the Middle East, and Africa. Since 2008 , the world has been hit by consecutive financial crises. From institutional crises (for instance, the bankruptcy of the Lehman Brothers investment company) to systemic crises (for instance, the actual collapse of European debt markets), national debt crises and currency crises (for instance, the challenges for the Eurozone), which resulted in a shakeout of the global financial system.

The continuous financial crises have definitely created a climate of distrust in the traditional financial system. Due to this, the Islamic financial industry can take advantage of the unprecedented opportunity and participate in the global dialogue on the financial system and its stainability.

This opportunity has been further secured by:

- strengthening the position of the member countries of the Organization of Islamic Cooperation;

- special attention paid to the industry at the international discussions of the financial system.

- Islamic finance is believed to have begun with the introduction of Islamic banking in the mid-70s. At the initial stages, the operational activities of Islamic banks were based on the principle of two-tier mudarabah:

- on the liabilities side, the depositor acted as an investor, while the bank acted as an entrepreneur;

- on the assets side, the bank acted as an investor, while the person attracting funds acted as an entrepreneur.

However, having passed through the four stages of development, the operating activity of banks, dominating the other Islamic finance activities in the industry, moved from two-tier mudarabah to two-tier murabaha. It was preconditioned by the fact that the assets were mainly financed with the murabaha financial instrument. 
services to low-income groups of people at a moderate price.

- Insufficient human capital development. The growing and intense competition between market participants in the Islamic financial industry has identified quantitative and qualitative human resources problems in the industry. That is why developing a conceptual policy and taking appropriate measures to solve these problems is of paramount importance.

- Perception of Islamic finance. Islamic finance is thought to be generally intended for holders of religious belief. While this is partly true, the core idea of Islamic finance is more profound. For instance, interest return (riba) is prohibited in Judaism, Christianity, and Buddhism and in many other religions and worldviews.

\section{CONCLUSION}

Even despite existing and potential problems, the Islamic finance projections seem positive. It proves the fact that Islamic finance has become common occurrence, and is now growing and developing. The revitalized interest in Islamic finance is testified by recent claims from the UK side on sukuk issuance and positioning itself as a "global centre for Islamic finance." The Middle Eastern countries and a number of their capitals (Dubai, Doha and Manama) seek to continue developing as centres of Islamic finance.

In 2013, Dubai declared its intention to become the capital of the Islamic economy. Kuala Lumpur still holds the leading positions in Islamic finance and economics. What is more, Islamic finance is also spreading in Turkey, Africa and Central Asia: the countries with emerging and transition economies introduce Islamic finance not only as a means of attracting capital for infrastructure projects, but also as an alternative channel for retail banking, finance and insurance.

The fact that Istanbul has been chosen to locate the World Bank's Centre of Excellence in Islamic Finance makes it evident that the Islamic finance industry is discovering new markets and extending its boundaries.

As the Islamic finance industry is developing, in the short and medium-term perspective, the trend towards changing sector activity is likely to continue. Islamic banking and the financial instrument market will continue dominating the industry in terms of size.

Islamic funds and takaful, despite their sustainable growth, are likely to maintain a modest share. However, it may be considered both a challenge and a favourable opportunity.

As the connection between the real and nominal economy becomes more prominent, these sectors are expected to become more significant. Another positive aspect in the Islamic financial industry development is its refocusing on solving social problems and financial inclusion. services. The financial services inclusion is a concept that has been relevant since the early 2000s. This concept was originally applied to providing financial 


\section{REFERENCES}

[1] Vagizova V.I., Igonina A.S. Mathematical and statistical forecasting of Islamic banking assets. 2014. Pp. 120-124.

[2] Danchenko E.A. The development of the banking products market based on Islamic banking. Rostov-on-Don. 2015. $231 \mathrm{p}$.

[3] Danchenko E.A. The paradigm of the formation of modern Islamic banking. 2015.

[4] Aji Mohd Rais Haji Alias Management briefing. Haji Mohd Rais Haji Alias. Zakat collection centre Federal territory Islamic religious council. $124 \mathrm{p}$.

[5] Faridi F.R. Theory of Fiscal Policy in an Islamic State // J. Res. Islamic Econ. 1983. No. 1. Pp. 15-30.

[6] Zhuravlev A. Yu. Conceptual basis of the Islamic economy. Islamic finance in the modern world: economic and legal aspects. Moscow. 2004. $154 \mathrm{p}$. 